\section{Modeling Daily Water Use of Hydrangea macrophylla and Gardenia jasminoides as Affected by Environmental Conditions}

\author{
Lucas O'Meara, Marc W. van Iersel ${ }^{1}$, and Matthew R. Chappell \\ Department of Horticulture, The University of Georgia, 1111 Miller Plant \\ Sciences Building, Athens, GA 30602-7273
}

Additional index words. evapotranspiration, daily light integral, load cell, modeling, woody ornamentals, crop coefficient

\begin{abstract}
Irrigation is an essential component of ornamental plant production, yet relatively little is known about how much water nursery crops require to maintain optimal growth rates. Our objectives were to precisely determine the daily water use (DWU) of Hydrangea macrophylla and Gardenia jasminoides grown in 6-L containers, quantify how this is affected by environmental conditions, develop a quantitative model describing DWU, evaluate this model with an independent data set, and determine the feasibility of using crop coefficients $\left(K_{c}\right)$ for irrigation scheduling. In 2010, we quantified the DWU of two Hydrangea macrophylla cultivars, Fasan and Pia. There was little difference in DWU of the two cultivars, which ranged from 50 to $300 \mathrm{~mL} / \mathrm{plant} / \mathrm{day}$ depending on plant age and environmental (hoophouse) conditions. In 2010, daily light integral (DLI) had the greatest influence on DWU with DWU increasing with increasing DLI. The combination of plant age, final leaf area, DLI, and their interactions explained $\mathbf{8 3 . 2 \%}$ and $90.8 \%$ of day-to-day variation in DWU of 'Fasan' and 'Pia', respectively. In July 2011, a follow-up study was conducted using Hydrangea macrophylla 'Fasan' and Gardenia jasminoides 'Radicans'. DWU of 'Fasan' ranged from 50 to $200 \mathrm{~mL} / \mathrm{plant} / \mathrm{day}$ and DWU of 'Radicans' ranged from 50 to $560 \mathrm{~mL} / \mathrm{plant} /$ day. The lower DWU of 'Fasan' in 2011 compared with 2010 was the result of stunted growth of the hydrangeas, a result of elevated temperatures within the hoophouse during the plants initial growth flush. Vapor pressure deficit (VPD) explained more of the daily fluctuations in DWU in 2011 compared with 2010. Predicting DWU of the 2011 'Fasan' crop using 2011 environmental conditions and the model developed using the 2010 data resulted in DWU estimates that were on average $64 \%$ too high. This discrepancy is likely the result of slower overall growth rate and a $15.4 \%$ reduction in 'Fasan' total growth in 2011 compared with 2010 and points to the challenges of modeling DWU. There were distinct seasonal changes in $K_{c}$ values for the crops, but the trends differed between 2010 and 2011. Our results suggest that an accurate measure of canopy size may improve performance of predictive water use models.
\end{abstract}

Global climate change and population growth have increased uncertainty about future availability of irrigation water for agricultural production (IPCC, 2007; Jury and Vaux, 2005; PCAST, 2012). As a result, water availability and use are becoming an increasingly important issue for specialty crops, including the nursery and floriculture industry (Lea-Cox et al., 2010; Vorosmarty et al., 2000). A more accurate assessment of plant water needs throughout a commercial production cycle and the development of quantitative irrigation guidelines and/or

\footnotetext{
Received for publication 8 May 2013. Accepted for publication 25 June 2013

This research was funded by the Center for Applied Nursery Research in Dearing, GA, and USDA-NIFASCRI (award no. 2009-51181-05768).

We thank Bob Teskey and John Ruter for their suggestions on an earlier version of the manuscript. ${ }^{1}$ To whom reprint requests should be addressed; e-mail mvanier@uga.edu.
}

weather-based irrigation models could assist nursery and floriculture growers in reducing their water use while still meeting the needs of their crops. This is especially true because growers often apply more water than their crops need (Fare et al., 1992), even when following best management practices (BMPs) for irrigation (Mathers et al., 2005). Recommended BMPs do not account for DWU differences among species or for daily fluctuations in DWU resulting from changing environmental conditions. The result is often overirrigation of nursery crops and a resultant increase in fertilizer and pesticide leaching and runoff that is capable of causing eutrophication of surface water bodies (Majsztrik et al., 2011) or contamination of groundwater (Brand et al., 1993; Mangiafico et al., 2009; McAvoy et al., 1992). Leaching of nutrients out of the container substrate also has been shown to reduce plant growth rates as a result of a long-term reduction in fertility (Million et al., 2007). Overwatering can also facilitate the development of pathogenic disorders in nursery stock such as Pythium and Phytophthora (Blaker and MacDonald, 1981) that cause reduced growth rate or crop losses. Because of the potential problems caused by excessive irrigation, estimating or monitoring DWU has been suggested as a method to improve irrigation efficiency and production of ornamental plants (Kim and van Iersel, 2009; Kim et al., 2011; van Iersel et al., 2010; Warsaw et al., 2009a, 2009b).

Although there are a variety of studies looking at water use of nursery crops, there is sparse information on the importance of different environmental factors in determining DWU. This is partly the result of water use measurements being taken only every few days or weeks (e.g., Warsaw et al., 2009b), making it impossible to develop quantitative relationships between DWU and environmental conditions. For example, Garcia-Navarro et al. (2004) and Warsaw et al. (2009a) measured water use of 30 species, but DWU measurements were not made daily nor were they correlated with corresponding environmental conditions to elucidate how environmental conditions affect DWU. Baille et al. (1994) measured DWU of nine ornamental species, including Gardenia jasminoides, and developed models to describe DWU. However, they evaluated their models using data from the same crop that was used for model development rather than with an independent data set. Niu et al. (2006) did measure DWU on a continual basis over $123 \mathrm{~d}$ and determined $\mathrm{K}_{\mathrm{c}}$ for five species of woody landscape species, but the results were not validated using an independent data set. Model evaluation using an independent data set has long been considered essential to test model performance (Reynolds and Acock, 1985).

By using sensors to monitor substrate moisture levels and environmental conditions, researchers have re-evaluated how much water various species require for optimal growth (Warsaw et al., 2009a) and what environmental factors play the largest role in determining plant water use (Kim et al., 2011; van Iersel et al., 2010). Knowing the actual volume of water lost on a daily basis through evapotranspiration and how the corresponding DWU is affected by environmental conditions over an entire production cycle can help with the development of more efficient irrigation scheduling protocols, enabling growers to apply precise volumes of water rather than repeatedly oversaturating the substrate.

Much of the work done in regard to modeling plant water use is based on evapotranspiration (ET) estimates, derived largely from the Penman-Monteith or similar equations (Jones and Tardieu, 1998). This equation was originally developed for agronomic crops, yet through modification of specific variables and the development of $\mathrm{K}_{\mathrm{c}}$ values for ornamental plant species, this approach has been used to estimate ET rates of nursery crops (Baille et al., 1994; Beeson and Brooks, 2008; Garcia-Navarro et al., 2004; Niu et al., 2006). Recent studies, using both soil moisture sensors (Kim et al., 2011; Warsaw et al., 
2009b) and weighing lysimeters (Baille et al., 1994; Beeson, 2011; Earl, 2003; GarciaNavarro et al., 2004; Niu et al., 2006) to quantify ET, have shown promise to quantify crop water needs in real time. Beeson (2012) showed that combining reference ET values with canopy closure measurements can accurately predict water use of woody evergreen shrubs in containers.

Our goal was to use daily lysimeter and environmental data to more precisely understand DWU over an entire production cycle in a production environment. Specific objectives were to 1) determine DWU of Hydrangea macrophylla and Gardenia jasminoides cultivars; 2) quantify and correlate how DWU is affected by environmental conditions; 3) develop a quantitative, environmental-based model describing DWU; 4) evaluate the hydrangea model with an independent data set; and 5) assess the feasibility of using simple models to predict water use.

\section{Materials and Methods}

2010: Hydrangea macrophylla. This experiment was conducted in an unheated double-layer, polyethylene-covered hoophouse covered with a $40 \%$ shadecloth at the Center for Applied Nursery Research (CANR) in Dearing, GA (USDA zone 8b). Thirty-two rooted cuttings of Hydrangea macrophylla 'Fasan' and 32 cuttings of $H$. macrophylla 'Pia' were transplanted into 6.0-L containers $(22.5 \mathrm{~cm}$ tall $\times 22 \mathrm{~cm}$ diameter) filled with a composted pine bark medium containing $1.97 \mathrm{~kg} \cdot \mathrm{m}^{-3}$ lime, $0.74 \mathrm{~kg} \cdot \mathrm{m}^{-3}$ Micromax (Everris, Dublin, $\mathrm{OH}), 0.74 \mathrm{~kg} \cdot \mathrm{m}^{-3}$ gypsum, $1 \mathrm{~kg} \cdot \mathrm{m}^{-3}$ Talstar (Bifenthrin 0.2\%; FMC Professional Solutions, Philadelphia, PA), and $1.98 \mathrm{~kg} \cdot \mathrm{m}^{-3}$ Osmocote Pro 18-6-12 9 month release fertilizer $(18.0 \mathrm{~N}-2.6 \mathrm{P}-10.0 \mathrm{~K}$; Everris $)$ in May 2010. These two cultivars were chosen to quantify potential differences in DWU between a large cultivar ('Fasan') and a smaller, more compact cultivar ('Pia'). The plants were placed in an $18-\mathrm{m}^{2}$ area and irrigated using pressure-compensated drip emitters $(2 \mathrm{LPH}$ WPCJ; Netafim USA, Fresno, CA) connected to dribble rings (DR4-12; Dramm, Manitowoc, WI). The system was controlled using a data logger (CR10; Campbell Scientific, Logan, UT) and multiplexer (AM25T; Campbell Scientific). The mass of a subset of eight plants, four of each species, was measured using eight individually calibrated load cells (LSP-10; Transducer Techniques, Temecula, CA) mounted on steel baseplates with the same 6.0-L containers mounted to acrylic platforms on top of the load cells, creating a potin-pot system that kept plants from dislodging from load cells. Plant mass was measured at 0000 and 2200 HR each day and the difference in these two measurements was used to quantify the amount of water that was lost during the day through ET. Thus, DWU was based on water use during a $22-\mathrm{h}$ period, assuming ET between 2200 and 0000 HR was negligible.

The data logger controlled irrigation by opening a solenoid valve (Jar Top Valve; Orbit Irrigation Products Inc., Bountiful, UT) at $2200 \mathrm{HR}$ for $30 \mathrm{~min}$, applying $1 \mathrm{~L}$ of water, to bring the substrate moisture level back to container capacity. Because DWU was well below $1 \mathrm{~L}$ at all times, this ensured that water availability would not limit ET. Leachate was allowed to drain for $90 \mathrm{~min}$ and the starting mass of each plant was recorded at $0000 \mathrm{HR}$ for the following day's measurement cycle. Photosynthetically active radiation $(P A R)$ was measured every 5 min using a quantum sensor (QSO-sun; Apogee, Logan UT) and integrated at $2355 \mathrm{HR}$ each night to calculate the DLI. Temperature and humidity were also measured at 5-min intervals using a temperature/humidity probe (HMP50; Vaisala, Woburn, MA). All measurements were taken with the data logger, which also calculated vapor pressure and VPD every 5 min using temperature and humidity measurements. Maximum, minimum, and daily average values were recorded for $P A R$, temperature, relative humidity, vapor pressure, saturation vapor pressure, and VPD. On the 48th day of the study, a second layer of $40 \%$ shadecloth was pulled over the hoophouse and left in place for the remainder of the study.

After $83 \mathrm{~d}$, when plants had reached a salable size, the leaf area of the eight plants mounted on load cells was measured with a leaf area meter (LI-3100; LI-COR, Lincoln, $\mathrm{NE}$ ). 'Fasan' leaf area was $3347 \pm 485 \mathrm{~cm}^{2}$ and 'Pia' leaf area was $2912 \pm 601 \mathrm{~cm}^{2}$. Containers were saturated underwater for $24 \mathrm{~h}$, drained for $1.5 \mathrm{~h}$, and their mass was measured at container capacity. They were then dried at $80^{\circ} \mathrm{C}$ for 2 weeks. The difference in container mass at saturation and when dry was used to determine the water content at container capacity, which was $2.04 \mathrm{~L} /$ container.

Reference ET values were obtained from a weather station located at CANR, which is located within $30 \mathrm{~m}$ of the hoophouse used in this study. This weather station is part of the Georgia Automated Environmental Monitoring Network (Hoogenboom, 1993) and calculates reference ET using the FAO-Penman Monteith equation (Allen et al., 1998). We used these weather data, located outside the hoophouse, because growers have easy access to such data. Although DWU likely is better correlated with the environmental conditions inside the hoophouse than with those of a nearby weather station, few nurseries monitor environmental conditions inside hoophouses. In addition, the Penman-Monteith equation should not be applied to such data because of the highly variable air movement and the lack of the required fetch in enclosed growing environments.

Crop coefficient values were calculated as DWU/reference ET. Note that this results in units of $\mathrm{L} \cdot \mathrm{m}^{-1}$ rather than the more conventional unitless $\mathrm{K}_{\mathrm{c}}$ values resulting from calculating $\mathrm{K}_{\mathrm{c}}$ as actual ET/reference ET. The advantage of using DWU as a substitute for ET is that DWU is a direct measurement of DWU that is less sensitive to plant spacing than ET. Only days without rain were used for calculation of $\mathrm{K}_{\mathrm{c}}$ values because rain effects on reference ET and DWU of the plants inside the hoophouse differed.

2011: Hydrangea macrophylla and Gardenia jasminoides. A second experiment was conducted in the same location during the summer and fall of 2011 to investigate differences in DWU of 'Fasan' in two growing seasons (2010 vs. 2011) and to compare two different ornamental species. Thirty-two rooted cuttings of both Hydrangea macrophylla 'Fasan' and Gardenia jasminoides 'Radicans' were transplanted into 6.0-L containers filled with the same pine bark-based substrate as was used before and arranged on the same drip irrigation system. Four additional load cells were added to the system, enabling DWU to be measured for six randomly chosen plants from each species compared with four plants in 2010 .

The transplanted 'Radicans' crop was placed in the hoophouse at the end of Apr. 2011; however, 'Fasan' cuttings were not available until early July. Data collection on both species began immediately after placement of the hydrangea 'Fasan' plants and the experiment lasted $145 \mathrm{~d}$ until 27 Nov. To increase variability in DLI, a second layer of $40 \%$ shadecloth was pulled over the existing $40 \%$ shadecloth already installed on the hoophouse on Day 33 and removed on Day 107. After $145 \mathrm{~d}$, the plants were harvested and leaf area was determined for both species (LI-3100; LI-COR). 'Fasan' leaf area was $2899 \pm 639 \mathrm{~cm}^{2}$ and 'Radicans' leaf area was $4298 \pm 303 \mathrm{~cm}^{2}$. Reference ET and $\mathrm{K}_{\mathrm{c}}$ values were obtained using the protocol developed in 2010.

Statistical analysis. The relationship among DWU, environmental conditions (DLI and average temperature, humidity, and VPD), final leaf area, time (days from the start of the study), and select interactions were analyzed using Pearson's correlation (Proc CORR, Statistical Analysis Software Version 9.2; SAS, Cary, NC). To develop a model describing DWU, these same factors were combined into a single model and stepwise selection was used to eliminate non-significant factors $(P>0.05)$ from the model. Partial $R^{2}$ values of the remaining significant factors were used to quantify the effect of various factors on DWU (Proc GLM; SAS).

Analysis of the data obtained in the 2011 study followed that of the 2010 data with a few exceptions. Given that the 2011 study began later in the year and ran for nearly twice as long as the 2010 study, plant growth and DWU were more dynamic in response to seasonal changes in environmental conditions. To better account for the wide range of light levels and temperatures over the course of the 2011 study, both linear and quadratic terms $\left(\right.$ time $^{2}, \mathrm{DLI}^{2}$, and $\mathrm{VPD}^{2}$ ) describing environmental and plant parameters were included in the correlation analysis and stepwise selection. The 2010 DWU model developed for 'Fasan' (including temperature, VPD, DLI $\times$ time, DLI $\times$ final leaf area, and DLI $\times$ time $\times$ final leaf area) was evaluated using data from the 2011 study to determine how well the model developed 

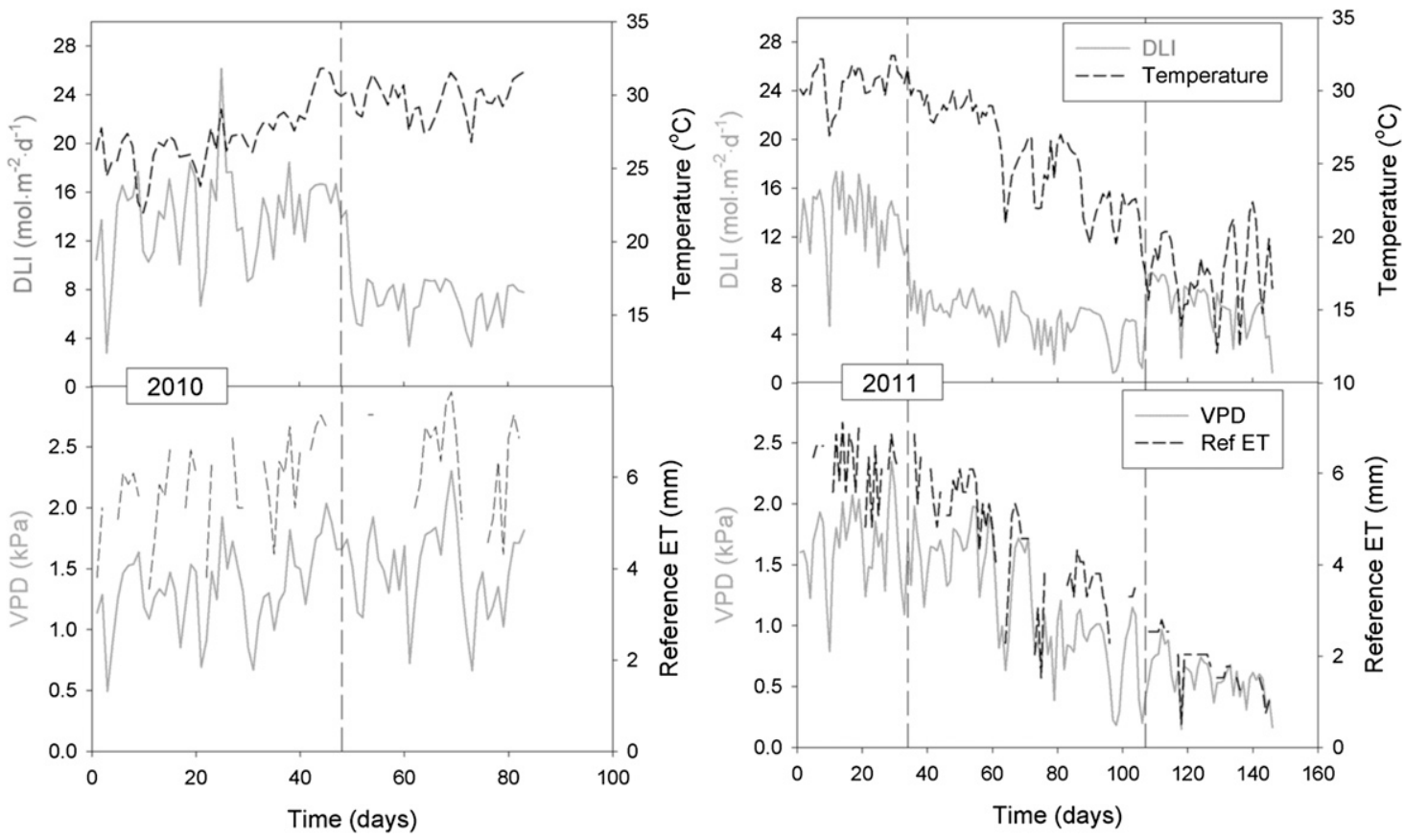

Fig. 1. Daily light integral (DLI), average daily temperature, and average daily vapor pressure deficit (VPD) inside the hoophouse and reference evapotranspiration (ET) outside of the hoophouse over the 85-d experiment in 2010 (left) and 145-d experiment in 2011 (right). DLI was reduced by the application of an additional layer of $40 \%$ shadecloth on Day 48 in 2010 (dashed vertical line) and from Day 34 until Day 107 in 2011. Only reference ET data on days without rain is shown.

with the data from 2010 could predict water use of the 2011 crop.

\section{Results and Discussion}

2010: Hydrangea macrophylla. Average daily temperature ranged from 22.0 to $31.2^{\circ} \mathrm{C}$ (Fig. 1). Daily light integral values ranged from 2.8 to $26.2 \mathrm{~mol} \cdot \mathrm{m}^{-2}$ before the application of the additional layer of shadecloth and were reduced to between 3.3 and $8.9 \mathrm{~mol} \cdot \mathrm{m}^{-2}$ thereafter (Fig. 1). Average daily VPD values were between 0.5 and $2.3 \mathrm{kPa}$ and reference ET between 3.4 and $7.9 \mathrm{~mm}$ with no clear trend over the course of the study (Fig. 1). Daily water use of both cultivars increased gradually from Day 0 to Day 48, ranging from 41 to $369 \mathrm{~mL} \cdot \mathrm{d}^{-1}$ (Fig. 2), likely mainly as the result of increasing plant size and increasing daylength. The application of the shadecloth on Day 48 resulted in an immediate and sustained decrease in DWU of both cultivars (Fig. 2) with values ranging from 120 to $358 \mathrm{~mL} \cdot \mathrm{d}^{-1}$. There was a reduction in DLI after the application of the shadecloth, whereas temperature and VPD remained similar (Fig. 1), suggesting that the drop in DWU was caused by lower DLI. The overall mean DWU of 'Fasan' (232 $\left.\mathrm{mL} \cdot \mathrm{d}^{-1}\right)$ was $12 \%$ higher than that of 'Pia' $\left(208 \mathrm{~mL} \cdot \mathrm{d}^{-1}\right)$. The DWU of both cultivars was only $2.5 \%$ to $15 \%$ of the water present in the substrate at container capacity, indicating that water use was never limited by water availability in the substrate.

Although there was no correlation between DLI and DWU (Table 1), there was a clear effect of DLI on DWU: on days with low DLI, DWU was low as well (e.g., Day 10, 79, 97, 106, 118; Fig. 2). Similarly, Kim et al.

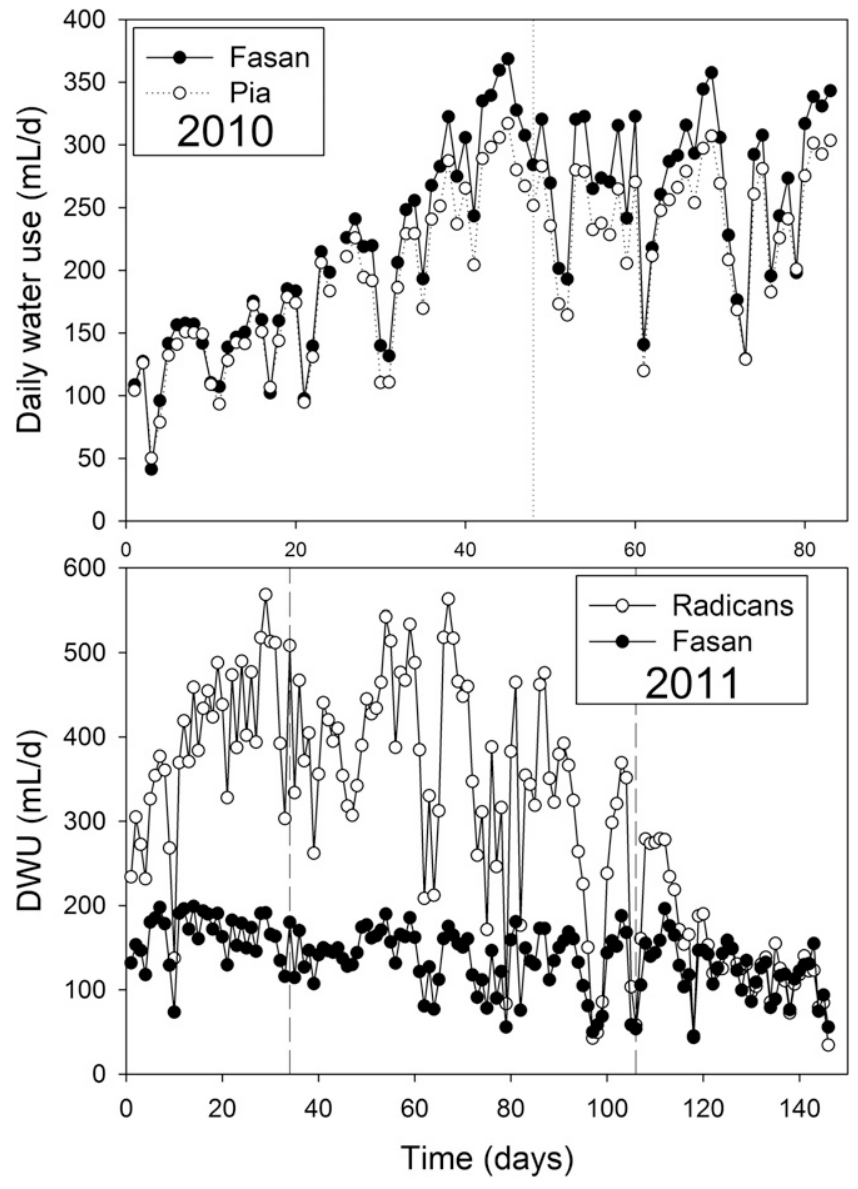

Fig. 2. Daily water use of Hydrangea macrophylla 'Fasan' and 'Pia' in 2010 (top) gradually increased from the onset of the study until Day 48, at which time additional shadecloth was added (dashed vertical line), resulting in lower daily water use (DWU) of both cultivars for the duration of the study. In 2011, daily water use of two species, Hydrangea macrophylla 'Fasan' and Gardenia jasminoides 'Radicans', was compared (bottom). The effect of the application of shadecloth was more pronounced in 'Radicans', resulting in decreased DWU during the period of shading (Days 34 to 106, indicated by dashed lines). 
(2011) found that despite a weak or absent correlation between DLI and DWU, DLI was still the most important factor in a model explaining DWU in Petunia $\times$ hybrida. There was, however, a strong correlation between DWU and the interaction of DLI and time in 'Fasan' (Table 2), indicating that the effect of DLI on DWU became larger over time. This was expected, because DWU of small plants is low irrespective of DLI but can vary much more when plants are larger and have a larger corresponding leaf area. The three-way interaction among DLI, time, and final leaf area had the strongest correlation with DWU in 'Pia' (Table 1) as a result of increasing plant size over time and relatively large differences in final leaf area among 'Pia' plants. Other factors correlated with DWU include time, temperature, VPD, final leaf area, and interactions between time $\times$ final leaf area and DLI $\times$ final leaf area ('Pia' only) (Table 1).

Most of these correlations make sense from a physiological perspective, because after a rooted cutting is transplanted, it will increase in size over time, enabling the plant to absorb more sunlight resulting in increased plant growth, transpirational surface area (leaf area), and associated water use. The increase in DWU with increasing VPD was expected, because the driving force for transpiration is

Table 1 . The relationship between 2010 daily water use (DWU) of two hydrangea cultivars ('Pia' and 'Fasan') and various parameters and their interactions as indicated by Pearson's correlation coefficients $(r)$ and significance $(P)$.

\begin{tabular}{lrcccc}
\hline & \multicolumn{2}{c}{ Fasan } & & \multicolumn{2}{c}{ Pia } \\
\cline { 2 - 3 } \cline { 5 - 6 } & $r$ & $P$ & & $r$ & $P$ \\
\hline Time & 0.646 & $<0.0001$ & & 0.581 & $<0.0001$ \\
DLI & 0.064 & 0.32 & & 0.077 & 0.24 \\
Temperature & 0.806 & $<0.0001$ & & 0.719 & $<0.0001$ \\
VPD & 0.750 & $<0.0001$ & & 0.690 & $<0.0001$ \\
LA & -0.169 & 0.0085 & & 0.413 & $<0.0001$ \\
Time * DLI & 0.885 & $<0.0001$ & & 0.804 & $<0.0001$ \\
Time * LA & 0.582 & $<0.0001$ & & 0.721 & $<0.0001$ \\
DLI * LA & 0.012 & 0.85 & & 0.234 & 0.0002 \\
DLI * LA * & 0.812 & $<0.0001$ & & 0.923 & $<0.0001$ \\
$\quad$ time & & & &
\end{tabular}

Time $=$ days from start of study; DLI = daily light integral; VPD = vapor pressure deficit; LA = final leaf area.

Table 2. The significant components of a model developed using stepwise selection to explain day-to-day fluctuations in daily water use of Hydrangea macrophylla 'Fasan' in 2010.

\begin{tabular}{llcc}
\hline Factor & $\begin{array}{c}\text { Parameter } \\
\text { estimate }\end{array}$ & $\begin{array}{c}\text { Partial } \\
R^{2}\end{array}$ & $P$ \\
\hline DLI * time & 0.474 & 0.784 & $<0.0001$ \\
VPD & 72.49 & 0.053 & $<0.0001$ \\
DLI $^{*}$ LA & -0.000372 & 0.032 & $<0.0001$ \\
DLI * LA * & -0.0000735 & 0.016 & $<0.0001$ \\
$\quad$ time & & & \\
Temperature & 7.94 & 0.012 & $<0.0001$ \\
Total & & 0.897 & $<0.0001$ \\
\hline
\end{tabular}

${ }^{z}$ The importance of different model components is indicated by the partial coefficient of determination $\left(R^{2}\right)$ and significance $(P)$.

Time $=$ days from start of study; DLI $=$ daily light integral; VPD = vapor pressure deficit; LA = final leaf area. the VPD between the stomatal cavity and the surrounding air. The negative correlation between DWU and final leaf area of 'Fasan' suggests that plants with a larger leaf area had a lower DWU. The reason for this is not clear but the correlation coefficient was low, indicating that the effect of final leaf area on DWU was small. Temperature is of importance because the vapor pressure of the stomatal cavity is temperature-dependent, whereas the vapor pressure of the surrounding air depends on both air temperature and dew point.

Using stepwise regression, we determined that $90 \%$ of day-to-day changes in DWU of 'Fasan' could be explained based on DLI, time, final leaf area, VPD, and temperature (Table 2). Ninety-five percent of DWU fluctuations of 'Pia' could be explained by the same variables and their specific interactions (Table 3). Comparing the measured DWU with the DWU as predicted by these regression equations showed a strong correlation between the two (Fig. 3). Eighty-three percent and $91 \%$ of day-to-day changes in DWU of 'Fasan' and 'Pia', respectively, could be explained based on the effects of time, DLI,

Table 3. The significant components of a model developed using stepwise selection to explain day-to-day fluctuations in daily water use of Hydrangea macrophylla 'Pia' in $2010 .{ }^{\mathrm{z}}$

\begin{tabular}{lccc}
\hline Factor & $\begin{array}{c}\text { Parameter } \\
\text { estimate }\end{array}$ & $\begin{array}{c}\text { Partial } \\
R^{2}\end{array}$ & $P$ \\
\hline DLI * LA * & 0.0000586 & 0.851 & $<0.0001$ \\
$\quad$ time & & & \\
VPD & 63.69 & 0.033 & $<0.0001$ \\
Time * LA & 0.000988 & 0.020 & $<0.0001$ \\
Time & -2.624 & 0.035 & $<0.0001$ \\
Temperature & 5.464 & 0.007 & $<0.0001$ \\
LA & -0.0119 & 0.002 & 0.0024 \\
Total & & 0.948 & $<0.0001$ \\
\hline
\end{tabular}

${ }^{2}$ The importance of different model components is indicated by the partial coefficient of determination $\left(R^{2}\right)$ and significance $(P)$.

Time $=$ days from start of study; DLI = daily light integral; $\mathrm{VPD}=$ vapor pressure deficit; $\mathrm{LA}=$ final leaf area. and final leaf area, whereas temperature and VPD explained only an additional $4 \%$ to $6.5 \%$ of day-to-day changes in DWU. This suggests that a reasonably accurate predictive water use model could be developed with DLI as the only environmental input. Using the effects of DLI, time, final leaf area, VPD, and temperature on DWU, we developed a predictive water use model to be tested for effectiveness using an independent data set obtained in the same production environment at CANR during the subsequent (2011) production cycle of 'Fasan' (Table 3).

2011: Hydrangea macrophylla and Gardenia jasminoides. Average daily temperature ranged from 12.1 to $32.4{ }^{\circ} \mathrm{C}$ (Fig. 1B). Before the application of an additional layer of shadecloth, DLI values were between 4.7 and $17.4 \mathrm{~mol} \cdot \mathrm{m}^{-2}$ (Fig. 1). During the $74 \mathrm{~d}$ under increased shade, DLI values dropped to 0.83 to $8.4 \mathrm{~mol} \cdot \mathrm{m}^{-2}$. Once shadecloth was removed in the fall, over the final $39 \mathrm{~d}$ of the study, DLI values were between 2.0 and $9.1 \mathrm{~mol} \cdot \mathrm{m}^{-2}$. Average daily VPD ranged from 0.15 to $2.35 \mathrm{kPa}$, whereas reference ET gradually declined from $\approx 6$ to $1 \mathrm{~mm}$ over the course of the study (Fig. 1).

During the first $33 \mathrm{~d}$ of the study, average DWU of 'Radicans' exhibited an overall increase from 230 to $570 \mathrm{~mL}$ (Fig. 2). During the $73 \mathrm{~d}$ under shade, DWU leveled off with values ranging from 50 to $560 \mathrm{~mL}$ and, in general, decreased as DLI and temperatures dropped. After the removal of the shadecloth, DWU values temporarily spiked to $275 \mathrm{~mL}$ but then gradually tapered to $\approx 100 \mathrm{~mL}$.

Daily water use of 'Fasan' ranged from 75 to $200 \mathrm{~mL}$ over the entirety of the experiment and there were no distinct seasonal changes in DWU (Fig. 2). As a result of average temperatures reaching over $30{ }^{\circ} \mathrm{C}$ for 24 of the first $33 \mathrm{~d}$ after the hydrangeas were placed in the hoophouse, the 'Fasan' crop did not produce a significant growth flush until early fall, explaining the steady DWU throughout summer. In fall, the growth flush of the plants did not result in increased DWU, probably because DLI and temperatures were dropping

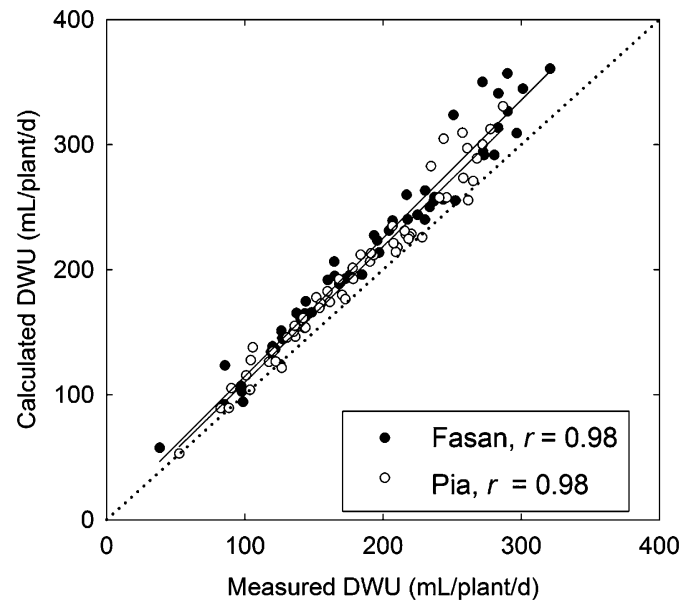

Fig. 3. Measured vs. modeled daily water use (DWU) of two Hydrangea macrophylla cultivars in 2010. Each data point represents the average of four plants. See Tables 2 and 3 for model parameters. The dotted line indicates a perfect model fit. 
at the same time, offsetting the effect of plant growth on DWU. Overall, day-to-day fluctuations in DWU of both species responded in a similar manner to changing environmental conditions. Like in 2010, changes in DWU were associated with DLI, although not well correlated (Table 4), with high DWU occurring on days with a high DLI (e.g., Day 7, 29, 54, 67) (Figs. 1 and 2). Daily water use also increased and decreased in close association with daily changes in VPD (Figs. 1 and 2).

Using stepwise regression, we found that only $40 \%$ of the variation in DWU of 'Fasan' was explained by time, final leaf area, and DLI combined (Table 4) as compared with $83 \%$ in 2010 (Table 2). However, by including the effects of VPD, we were able to explain an additional $28 \%$ of fluctuations in DWU in 'Fasan'. Of DWU fluctuations in 'Radicans', 57\% was explained by the combination of time, final leaf area, and DLI (Table 5). By including VPD, an additional $30 \%$ of day-to-day changes in DWU of 'Radicans' could be explained.

Environmental effects on DWU. Our finding that DLI was the most important environmental variable affecting plant water use

Table 4. The significant components of a model developed using stepwise selection to explain day-to-day fluctuations in daily water use of Hydrangea macrophylla 'Fasan' in 2011. ${ }^{2}$

\begin{tabular}{lccr}
\hline Factor & $\begin{array}{c}\text { Parameter } \\
\text { estimate }\end{array}$ & $\begin{array}{c}\text { Partial } \\
R^{2}\end{array}$ & $P$ \\
\hline DLI * LA & 0.00165 & 0.392 & $<0.0001$ \\
Time * VPD & 0.956 & 0.231 & $<0.0001$ \\
DLI * VPD & 2.022 & 0.048 & $<0.0001$ \\
Time & -0.236 & 0.008 & $<0.0001$ \\
VPD * VPD & -6.099 & 0.003 & 0.0059 \\
Total & & 0.682 & $<0.0001$ \\
\hline
\end{tabular}

${ }^{2}$ The importance of different model components is indicated by the coefficient of determination $\left(R^{2}\right)$ and significance $(P)$.

Time $=$ days from start of study; DLI = daily light integral; VPD = vapor pressure deficit; LA = final leaf area.

Table 5. The significant components of a model developed using stepwise selection to explain day-to-day fluctuations in daily water use of Gardenia jasminoides 'Radicans' in 2011. ${ }^{2}$

\begin{tabular}{lccc}
\hline Factor & $\begin{array}{c}\text { Parameter } \\
\text { estimate }\end{array}$ & $\begin{array}{c}\text { Partial } \\
R^{2}\end{array}$ & $P$ \\
\hline Time * time & -0.0292 & 0.522 & $<0.0001$ \\
Time * DLI * & 0.202 & 0.266 & $<0.0001$ \\
$\quad$ VPD & & & \\
Time * LA * & 0.000507 & 0.038 & $<0.0001$ \\
$\quad$ VPD & & & \\
DLI * DLI & -1.689 & 0.016 & $<0.0001$ \\
DLI * LA * & -0.0000358 & 0.017 & $<0.0001$ \\
$\quad$ time & & & \\
DLI * LA & 0.00150 & 0.004 & $<0.0001$ \\
Time & 5.087 & 0.002 & 0.0011 \\
DLI & 52.788 & 0.004 & $<0.0001$ \\
Time * DLI & -0.335 & 0.006 & $<0.0001$ \\
Total & & 0.875 & $<0.0001$ \\
\hline
\end{tabular}

${ }^{\mathrm{z}}$ The importance of different model components is indicated by the partial coefficient of determination $\left(R^{2}\right)$ and significance $(P)$.

Time $=$ days from start of study; DLI $=$ daily light integral; VPD = vapor pressure deficit; LA = final leaf area. in the 2010 is consistent with earlier studies conducted on Gardenia jasminoides (Baille et al., 1994), Lantana camara and Abutilon $\times$ hybridum (Kim and van Iersel, 2009), $\mathrm{Ka}$ lanchoe blossfeldiana (Löfkvist et al., 2009), and Petunia $\times$ hybrida (van Iersel et al., 2010). In contrast to 2010, when DLI was the only environmental variable with a large impact on daily water use, in 2011, both DLI and VPD were important in explaining dayto-day changes in water use by both species. The reason for this difference between the 2010 and 2011 crops is not clear but may be related to the time of year the data were collected (spring to summer in 2010 and summer to fall in 2011). Baille et al. (1994) developed water models of nine ornamental species based on separate contributions of radiation and advection (essentially VPD) and found that for most species, including Gardenia jasminoides, radiation was more important than advection. However, this ratio was greatly variable among species with the radiative component accounting for $88 \%$ in Gardenia jasminoides but only $45 \%$ to $46 \%$ in Begonia $\times$ hiemalis and Euphorbia pulcherrima.

Predictive modeling. Predicting DWU of the 2011 'Fasan' crop using 2011 environmental conditions and the regression model developed using the 2010 data resulted in DWU estimates that generally were $33 \%$ to $98 \%$ too high, except for the $5 \mathrm{~d}$ with the lowest DLI and VPD for which the model underestimated DWU by $30 \%$ to $87 \%$ (Fig. 4). The correlation between measured and predicted DWU $(r=0.82)$ suggests that the model effectively predicted days of low vs. high water use but did not accurately predict the DWU values. The inability of the 2010 model to accurately predict DWU in 2011 is likely the result of differences in 'Fasan' growth between 2010 and 2011; there was more vegetative growth early in the growing season in 2010 than in 2011, resulting in differences in canopy size between the 2 years. The 2010 model contains the variable time as a proxy for canopy size with final leaf area accounting for differences in leaf area among the plants and the time $\times$ final leaf area interaction representing differences in leaf area development among the different plants over the course of the growing season. In 2010, time may have been a good proxy for canopy size, but applying the 2010 model to the 2011 data assumes similar growth over time in both years. However, in 2011, the crop did not grow much until fall and the different growth patterns in 2010 and 2011 likely explain why the 2010 model overestimated water use in 2011. This discrepancy emphasizes the importance of including accurate estimates of canopy size into predictive water use models. Baille et al. (1994) also recognized the importance of canopy size in their models, but rather than developing a model for water use of Gardenia jasminoides that takes into account canopy size, they developed separate models for crops with different leaf area index (LAI). One drawback to LAI measurements is that they are destructive and time-consuming and therefore not feasible on a commercial scale. Million et al. (2011) addressed the issue of changing canopy size by developing a model for Viburnum odoratissimum that not only simulates plant water requirements, but also plant growth and development as well as nutrient requirements, leaching, and nitrogen losses. Beeson (2012) has recently demonstrated the effectiveness of $\mathrm{ET}_{\mathrm{o}}$-based irrigation in conjunction with percent canopy closure measurements. Using such a measurement would be a simple and non-destructive way to track seasonal changes in plant growth rates, likely increasing the accuracy of a plant water use model. A similar approach would be to use canopy light interception or the normalized difference vegetation index (NDVI) as a measure of plant size. Alternatively, Bauerle and Bowden (2011) showed that tree water use can be modeled based on environmental conditions combined with detailed canopy structure data and leaf morphological and physiological parameters. Regardless, our results indicate the complexities

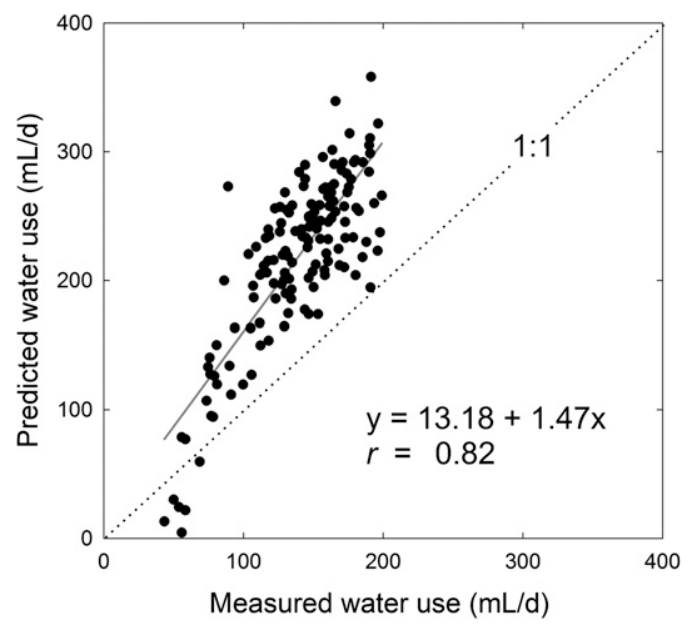

Fig. 4. Daily water use (DWU) of Hydrangea macrophylla 'Fasan' in 2011 as compared with the water use as predicted by the model developed using 2010 data (see Table 2 for details). On average, the predicted water use is $64 \%$ higher than the measured water use. 
involved in determining predictive water use models and the importance in accounting for canopy size to adjust for crop size differences from year to year or season to season.

Crop coefficients. In $2010, \mathrm{~K}_{\mathrm{c}}$ for both hydrangea cultivars increased rapidly and linearly during the first $48 \mathrm{~d}$ (Fig. 5), as is typical for a rapidly growing crop (Allen et al., 1998), and the higher water use of 'Fasan' compared with 'Pia' (Fig. 2) resulted in a higher $\mathrm{K}_{\mathrm{c}}$ for 'Fasan'. The application of the shadecloth resulted in an immediate decrease in the $\mathrm{K}_{\mathrm{c}}$ of both cultivars and also reduced the rate at which $\mathrm{K}_{\mathrm{c}}$ increased over time. The reduction of $K_{c}$ in response to the additional shade is the result of the weather station monitoring outdoor environmental conditions. The reference ET is thus not based on the conditions in the hoophouse and therefore unaffected by the shade. Because the shade did have a pronounced impact on DWU of both cultivars, shading resulted in a decrease in $\mathrm{K}_{\mathrm{c}}$.

In 2011, $\mathrm{K}_{\mathrm{c}}$ for Gardenia jasminoides also increased rapidly during the early part of the study and decreased when the additional shade was applied on Day 34 (Fig. 5). The $\mathrm{K}_{\mathrm{c}}$ continued to increase, at a slower rate, until
Day 70, after which there was no clear trend in $\mathrm{K}_{\mathrm{c}}$. During the latter half of the study, $\mathrm{K}_{\mathrm{c}}$ showed large day-to-day fluctuations and there was no apparent effect of the removal of the additional shadecloth on $\mathrm{K}_{\mathrm{c}}$. The $\mathrm{K}_{\mathrm{c}}$ value for Hydrangea macrophylla 'Fasan' was low and stable during the first $50 \mathrm{~d}$ with no apparent effect of the application of the shadecloth, likely the effect of static plant size until the onset of the fall growth flush. The hydrangea $\mathrm{K}_{\mathrm{c}}$ then gradually increased from Day 50 until the end of the study. As was the case for gardenia, there was no clear effect of the removal of the shadecloth on $\mathrm{K}_{\mathrm{c}}$. These results reveal some of the challenges associated with using $\mathrm{K}_{\mathrm{c}}$ values for irrigation scheduling of ornamental crops, specifically because commercial nurseries often have a variety of microclimates, including those inside greenhouses. Ideally, all microclimates would be quantified, but this would require extensive instrumentation. In addition, even within a greenhouse, there can be large variability in air movement (Fernandez and Bailey, 1994), making it difficult to collect accurate data that is applicable to an entire growing area. Also, ornamental crops are not always planted during the same season of the year, an

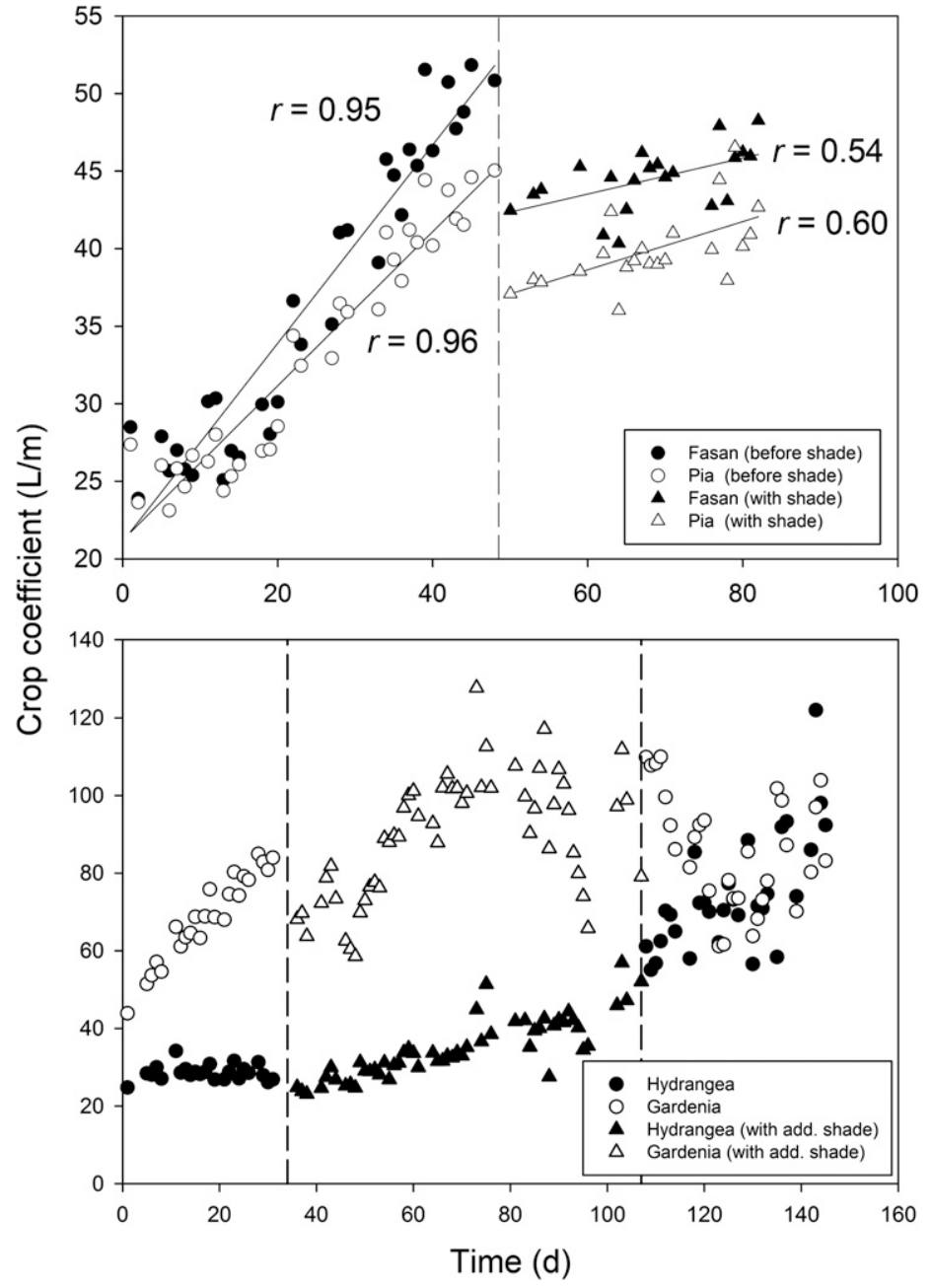

Fig. 5. Crop coefficients over the course of the 2010 (Hydrangea macrophylla 'Fasan' and Gardenia jasminoides 'Radicans') and 2011 (Hydrangea macrophylla 'Fasan' and 'Pia') studies. Dashed lines indicate the application and, in 2011, removal of an additional layer of shadecloth. important difference with agronomic crops, which are typically planted at specific times of the year, and as a result, different plantings of the same crop may have different growth rates. Such differences cannot easily be accounted for with $\mathrm{K}_{\mathrm{c}}$ values unless $\mathrm{K}_{\mathrm{c}}$ values would be determined for all possible cropping cycles. Further complicating this, ornamental crops are grown in different size containers and with different plant spacing, which would also affect $\mathrm{K}_{\mathrm{c}}$ values, even within a crop. Thus, determining appropriate $\mathrm{K}_{\mathrm{c}}$ values for all possible cropping situations seems infeasible. As a result, the practicality of using $\mathrm{K}_{\mathrm{c}}$ values for irrigation management of ornamental crops has been questioned (Bacci et al., 2008; Schuch and Burger, 1997). However, because $\mathrm{K}_{\mathrm{c}}$ is generally related to canopy size (Allen et al., 1998), it may be possible to develop $\mathrm{K}_{\mathrm{c}}$ values, particularly on high-value crops [e.g., Rosa 'Radrazz' (also known as 'Knockout')] and/or crops with specific production start and end dates (e.g., Euphorbia pulcherrima) as a function of non-destructive measurements of the leaf area index or a related canopy size parameter.

\section{Conclusions}

Load cells accurately quantified seasonal and environmentally induced changes in DWU. Daily light integral and VPD were the most influential environmental factors affecting day-to-day fluctuations in DWU. However, a predictive model developed using the 2010 data did not accurately predict DWU of the 2011 'Fasan' crop, likely as a result of differences in plant growth between the 2 years. Similar issues hinder the use of $\mathrm{K}_{\mathrm{c}}$ values for irrigation scheduling in nurseries: changes in $\mathrm{K}_{\mathrm{c}}$ over time differed greatly during two production cycles of the same crop, highlighting the difficulty of determining usable $\mathrm{K}_{\mathrm{c}}$ values. Accurate measures of plant size such as percent canopy closure, light interception, or NDVI may be necessary to account for seasonal differences in growth. If such measures can be successfully integrated into predictive water use models, such models may be used to automatically adjust irrigation volume and/or frequency, making nursery production more efficient and reducing its environmental impact.

\section{Literature Cited}

Allen, R.G., L.S. Pereira, D. Raes, and M. Smith 1998. Crop evapotranspiration-Guidelines for computing crop water requirements-FAO Irrigation and drainage paper 56 . FAO, Rome, Italy

Bacci, L., P. Battista, and B. Rapi. 2008. An integrated method for irrigation scheduling of potted plants. Sci. Hort. 116:89-97.

Baille, M., A. Baille, and J.C. Laury. 1994. A simplified model for predicting evapotranspiration rate of nine ornamental species vs. climate factors and leaf area. Sci. Hort. 59:217-232.

Bauerle, W.L. and J.D. Bowden. 2011. Separating foliar physiology from morphology reveals the relative roles of vertically structured transpiration factors within red maple crowns and limitations of larger scale models. J. Expt. Bot. 62:4295-4307. 
Beeson, R.C. 2011. Weighing lysimeter systems for quantifying water use and studies of controlled water stress for crops grown in low bulk density substrates. Agr. Water Mgt. 98:967-976.

Beeson, R.C. 2012. Development of a simple reference evapotranspiration model for irrigation of woody ornamentals. HortScience 47: 264-268.

Beeson, R.C. and J. Brooks. 2008. Evaluation of a model based on reference crop evapotranspiration $\left(\mathrm{ET}_{\mathrm{o}}\right)$ for precision irrigation using overhead sprinklers during nursery production of Ligustrum japonica. Acta Hort. 792:85-90.

Blaker, N.S. and J.D. MacDonald. 1981. Predisposing effects of soil moisture extremes on the susceptibility of Rhododendron to Phytophthora root and crown rot. Phytopathology 71: 831-834.

Brand, M.H., R.J. McAvoy, and E.G. Corbett. 1993. Nitrate loading to the soil profile underlying two containerized nursery crops supplied controlled release fertilizer. J. Environ. Hort. 11:82-85.

Earl, H.J. 2003. A precise gravimetric method for simulating drought stress in pot experiments. Crop Sci. 43:1868-1873.

Fare, D.C., C.H. Gillam, and G.J. Keever. 1992. Monitoring irrigation at container nurseries. HortTechnology 2:75-78.

Fernandez, J.E. and B.J. Bailey. 1994. The influence of fans on environmental conditions in greenhouses. J. Agr. Eng. Res. 58:201-210.

Garcia-Navarro, M.C., R.Y. Evans, and R.S. Montserrat. 2004. Estimation of relative water use among ornamental landscape plants. Sci. Hort. 99:163-174.

Hoogenboom, G. and K. Hatcher. 1993. The Georgia automated environmental monitoring network, p. 398-402. In: Hatcher, K. (ed.). Proc. of the 1993 Georgia Water Resources Conference. The University of Georgia, Athens, GA.

IPCC. 2007. Climate change 2007: Synthesis report. 18 July 2013. <http://www.ipcc.ch/pdf/ assessment-report/ar4/syr/ar4_syr.pdf >.
Jones, H.G. and F. Tardieu. 1998. Modeling water relations of horticultural crops: A review. Sci. Hort. 74:21-46.

Jury, W.A. and H. Vaux. 2005. The role of science in solving the world's emerging water problems. Proc. Natl. Acad. Sci. USA 102:1571515720.

Kim, J. and M.W. van Iersel. 2009. Daily water use of abutilon and lantana at various substrate water contents. Proc. Southern Nursery Assn. 54:12-16.

Kim, J., M.W. van Iersel, and S. Burnett. 2011. Estimating daily water use of two petunia cultivars based on plant and environmental factors. HortScience 46:1287-1293.

Lea-Cox, J.D., C. Zhao, D.S. Ross, T.E. Bilderback, J.R. Harris, S.D. Day, C. Hong, T.H. Yeager, R.C. Beeson, W.L. Bauerle, A.G. Ristvey, M. Lorscheider, S. Dickinson, and J.M. Ruter. 2010. A nursery and greenhouse online knowledge center: Learning opportunities for sustainable practice. HortTechnology 20:509-517.

Löfkvist, K., R. Larsen, J.E. Englund, and B.W. Alsanius. 2009. Light integral as an indicator of water use in commercial greenhouse nurseries. Acta Agr. Scandinavica Sect. B-Soil and Plant Sci. 59:326-334.

Majsztrik, J., A.G. Ristvey, and J.D. Lea-Cox. 2011. Water and nutrient management in the production of container-grown ornamentals. In: Hort. Reviews J. Janick (Ed.). Wiley, Hoboken, NJ. Hort. Rev. 38:253-297.

Mangiafico, S.S., J. Newman, D.J. Merhaut, J. Gan, B. Faber, and L. Wu. 2009. Nutrients and pesticides in stormwater runoff and soil water in production nurseries and citrus and avocado groves in California. HortTechnology 19:360 367.

Mathers, H.M., T.H. Yeager, and L.T. Case. 2005. Improving irrigation water use in container nurseries. HortTechnology 15:8-12.

McAvoy, R.J., M.H. Brand, E.G. Corbett, J.W. Bartok, Jr., and A. Botacchi. 1992. Effect of leachate fraction on nitrate loading to the soil profile underlying a greenhouse crop. J. Environ. Hort. 10:167-171.

Million, J., T. Yeager, and J. Albano. 2007. Consequences of excessive overhead irrigation on runoff during container production of sweet viburnum. J. Environ. Hort. 25:117-125.

Million, J.B., J.T. Ritchie, T.H. Yeager, C.A. Larsen, C.D. Warner, and J.P. Albano. 2011. CCROPSimulation model for container-grown nursery plant production. Sci. Hort. 130:874-886.

Niu, G., D.S. Rodrigues, R. Cabrera, C. McKenney, and W. Mackay. 2006. Determining water use and crop coefficients of five woody landscape plants. J. Environ. Hort. 24:160-165.

PCAST. 2012. Report to the president on agricultural preparedness and the agriculture research enterprise. Executive office of the President. President's Council of Advisors on Science and Technology.

Reynolds, J.F. and B. Acock. 1985. Predicting the response of plants to increasing carbon dioxide: A critique of plant growth models. Ecol. Modell. 29:107-109.

Schuch, U.K. and D.W. Burger. 1997. Water use and crop coefficients of woody ornamentals in containers. J. Amer. Soc. Hort. Sci. 122:727-734.

van Iersel, M.W., S. Dove, J.-G. Kang, and S.E. Burnett. 2010. Growth and water use of petunia as affected by substrate water content and daily light integral. HortScience 45:277-282.

Vorosmarty, C.J., P. Green, J. Salisbury, and R.B. Lammers. 2000. Global water resources: Vulnerability from climate change and population growth. Science 289:284-288.

Warsaw, A.L., R.T. Fernandez, B.M. Cregg, and J.A. Andresen. 2009a. Water conservation, growth, and water use efficiency of containergrown woody ornamentals irrigated based on daily water use. HortScience 44:1308-1318.

Warsaw, A.L., R.T. Fernandez, B.M. Cregg, and J.A. Andresen. 2009b. Container-grown ornamental plant growth and runoff nutrient content and volume under four irrigation treatments. HortScience 44:1573-1580. 